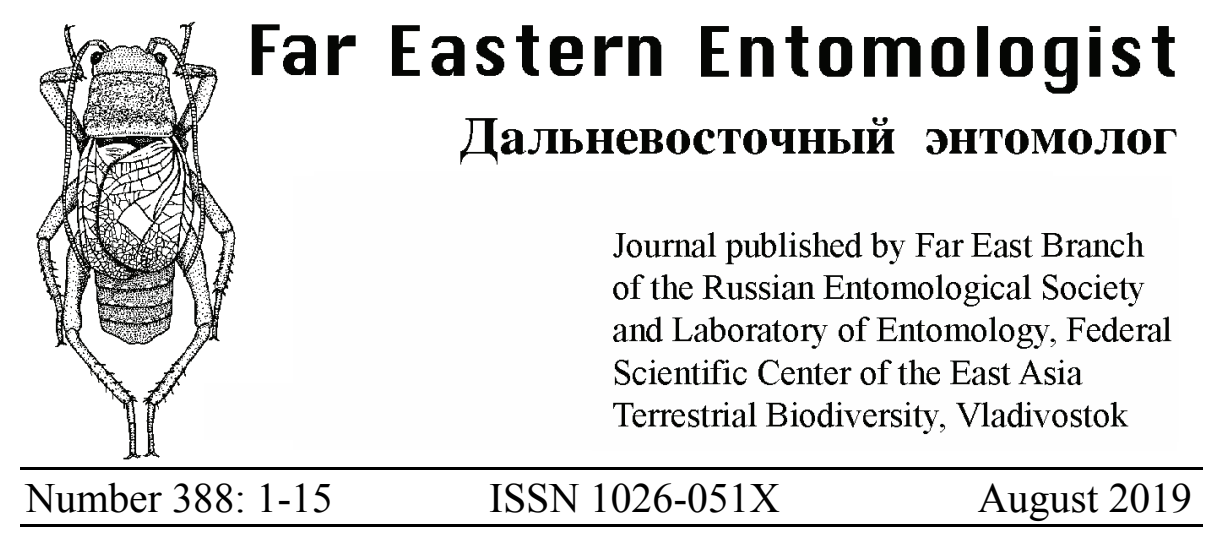

Journal published by Far East Branch of the Russian Entomological Society and Laboratory of Entomology, Federal Scientific Center of the East Asia Terrestrial Biodiversity, Vladivostok

http://zoobank.org/References/3B75C2B4-8FE8-46A1-815F-C4063434ED6B

\title{
NEW DATA ON THE NOMINATIVE SUBGENUS OF THE GENUS MACROSIPHONIELLA DEL GUERCIO, 1911 (HEMIPTERA: APHIDIDAE) FROM PALAEARCTIC
}

\section{R. Kh. Kadyrbekov}

Institute of Zoology, Ministry of Education and Sciences of Kazakhstan Republic, Al-Farabiav.93, Almaty,050060, Kazakhstan.E-mail: rustem_aijan@mail.ru

Summary. Two new taxa of aphids from genus Macrosiphoniella Del Guercio, 1911 (Hemiptera: Aphididae, Macrosiphini) are described from Kazakhstan. M. (s. str.) aizhanae Kadyrbekov sp. n. from South Kazakhstan region (West Tien Shan) collected on Pseudolinosyris grimii. This new species is most similar to M. tapuskae (Hottes et Frison, 1931) in the depth of the frontal groove and the large size of the body but differs from latter by shorter siphunculi ratio to the body length, by cauda length, by the proportion of the processus terminalis to the base of the 6th antennal segment. M. (s. str.) scopariae deserticola Kadyrbekov, subsp. n. from sandy deserts of South Kazakhstan inhabits Artemisia (Oligosporus) spp. The new subspecies is basically similar to the M. scopariae scopariae Bozhko, 1959, but differs from nominative subspecies by the absence of antesiphuncular and other sclerites on the abdomen in all seasonal morphs, lighter coloring of the head, antennae and legs in apterous viviparous females. New synonymy is proposed: Macrosiphoniella altaica Ivanovskaja, $1971=$ M. longirostrata Holman et Szelegiewicz, 1974, syn. n.; Macrosiphoniella aktashica aktashica (Nevsky, 1928) = M. aktashica hirsuta (Danijarova, 1979), syn. n. Macrosiphoniella khinganica Pashtshenko, 1998, stat. n. is considered as distinct species. A key to light colored Palaearctic species of the subgenus Macrosiphoniella that lack dark sclerites on the abdomen is also provided. 
Key words: aphids, Aphididae, Macrosiphini, Macrosiphoniella, taxonomy, new taxa, new synonymy, key.

Р. Х. Кадырбеков. Новые данные по номинативному подроду рода Macrosiphoniella Del Guercio, 1911 (Hemiptera: Aphididae) из Палеарктики // Дальневосточный энтомолог. 2019. N 338. С. 1-15.

Резюме. С территории Казахстана описаны два новых таксона рода Macrosiphoniella Del Guercio, 1911 (Hemiptera: Aphididae, Macrosiphini). M. (s. str.) aizhanae Kadyrbekov, sp. n. живет на Pseudolinosyris grimii в Южно-Казахстанской области (Западный Тянь-Шань). Новый вид по глубине лобного желобка и размеру тела близок к M. tapuskae (Hottes et Frison, 1931) и отличается от него соотношением длины трубочек к длине тела, длине хвостика, также пропорцией шпица к основанию 6-го членика усиков. M. scopariae deserticola Kadyrbekov, subsp. n. живет на полынях подрода Oligosporus в песчаных пустынях Южного Казахстана. Новый подвид в основном сходен с номинативным, но отличается от M. scopariae scopariae Bozhko, 1959 отсутствием предтрубочных и других склеритов на брюшке у всех сезонных морф, более светло окрашенными головой, усиками и конечностями у бескрылых живородящих самок, более низкой пропорцией трубочек к телу и большим количеством волосков на хвостике. Установлена новая синонимия: Macrosiphoniella altaica Ivanovskaja, 1971 = M. longirostrata Holman et Szelegiewicz, 1974, syn. n.; Macrosiphoniella aktashica aktashica (Nevsky, 1928) = M. aktashica hirsuta (Danijarova, 1979), syn. n. Статус Macrosiphoniella khinganica Pashtshenko, 1998, stat. n. повышен до видового ранга. Составлена определительная таблица для светло-зеленых и зеленых палеарктических видов подрода Macrosiphoniella, у которых отсутствуют предтрубочные и другие склериты на брюшке.

\section{INTRODUCTION}

Macrosiphoniella Del Guercio, 1911 is a large Holarctic genus of aphids with 150 species and subspecies in the world fauna, most of which inhabit the Palaearctic region (Favret, 2018). Known species are trophically associated with plants of the Compositae (Asteraceae) from the subtribes Antemideae and Artemiseae; some species inhabit plants of the subtribe Cynareae, and others (Polyakov, 1967). They live on aboveground parts of plants, oligophagous, narrow oligophagous and monophagous.

When processing materials collected in recent years in various regions of Kazakhstan, two new taxa have been discovered, described below. Holotypes and paratypes of new taxa are stored in the collection of the Institute of Zoology of the Committee of Science of the Ministry of Education and Science of the Republic of Kazakhstan (Almaty). All measurements in the text are in millimeters.

For compiling a key to species for light colored Palaearctic species of a nominative subgenus that lack dark sclerites on the abdomen, the key to European (Hille Ris 
Lambers, 1956; Heie, 1995) and Far Eastern species (Miyazaki, 1971; Pashtshenko, 1998 ) as well as the primary descriptions of species (Nevsky, 1929; Bozhko, 1953; Hille Ris Lambers, 1956; Narzikulov, 1958; Szelegiewicz, 1963; Umarov, 1964, 1966; Verma, 1971; Ivanovskaja, 1971; Holman \& Szelegiewicz, 1974; Basu \& Raychaudhuri, 1976; Szelegiewicz, 1978, 1980; Zhang \& Zhong, 1980; Pashtshenko, 1998; Zhang et al., 1999; Kadyrbekov, 2000; Kadyrbekov et al., 2002; Kadyrbekov, 2015) were used.

\section{TАХOMOMY}

Macrosiphoniella (s.str.) aizhanae Kadyrbekov, sp. n.

http://zoobank.org/NomenclaturalActs/5D1DDC02-42EA-4867-8CA2-6D3F0CCD6D25

Figs $1-5$

TYPE MATERIAL. Holotype: apterous viviparous female, slide No 5066, Kazakhstan: South Kazakhstan region, West Tien Shan, Karzhantau Range, Kyrykkyz pass, h 1861 m, on Pseudolinosyris grimii (Rgl. et Schrenk) Novopokr., 11.VIII 2014, leg. R.Kh. Kadyrbekov. Paratypes: 21 apterous viviparous females together with holotype.

DESCRIPTION. Apterous viviparous female (by 22 specimens). Body oval, 2.29-2.88. Frontal groove is very deep with distinct antennal tubercles, 0.25-0.35 of the distance between bases of first antennal segments (Fig. 1). Frontal hairs (0.050-0.060) long, pointed, 1.3-1.5 of basal diameter of 3rd antennal segment. Antennae normal, six-segmented, $0.94-1.25$ of body length. Third segment 1.251.55 of 4 th one, $0.80-0.95$ of 6 th segment, $1.05-1.25$ of the processus terminalis (Fig. 2). Processus terminalis 3.0-3.8 of the base of 6th segment. Secondary rhinaria in number 6-17 developed on the middle half of the 3rd segment (Fig. 2). Hairs on the 3rd segment $(0.030-0.035)$ pointed, $0.75-0.85$ of its basal diameter. Rostrum reaches before or behind of the hind coxae. Its ultimate rostral segment straight, not stiletto shaped (Fig. 3) $0.8-0.9$ of the second segment of hind tarsus, $0.60-0.77$ of the base of 6th segment with 6 accessory hairs. Siphunculi cylindrical with not distinct flanges, $0.14-0.18$ of body length, $0.9-1.0$ of cauda length (Fig. 4). Reticulated zone developed on the $0.25-0.35$ of their length. Cauda finger-shaped with pointed apex, 2.3-2.9 of the second segment of hind tarsus with 10-17 hairs (Fig. 5). Second segment of hind tarsus $0.80-0.95$ of the base of 6th antennal segment. Dorsal hairs $(0.050-0.060)$ pointed $1.3-1.5$ of the basal diameter of $3 \mathrm{rd}$ antennal segment. There are 10 hairs on 3 rd tergite, 4 between siphunculi and 6-8 ones on the 8 th tergite. Genital plate broad oval with 2 hairs on disk and 5-8 ones along its posterior margin. Legs normal developed. First tarsal segment with 3:3:3 hairs.

COLOR ON SLIDE. Head, clypeus, ultimate rostral segment, 1st, 2nd, middle and apex of 3rd, apex of 4th, 5-6th antennal segments, anal and genital plates, sclerites in base of dorsal hairs on 6-8th tergites are pale-brownish; apices of femora, tibiae (occasionally with light brownish middle parts), tarsi, siphunculi (except of base) are dark brownish. Cauda is pale. Antesiphuncular sclerites are absent. 


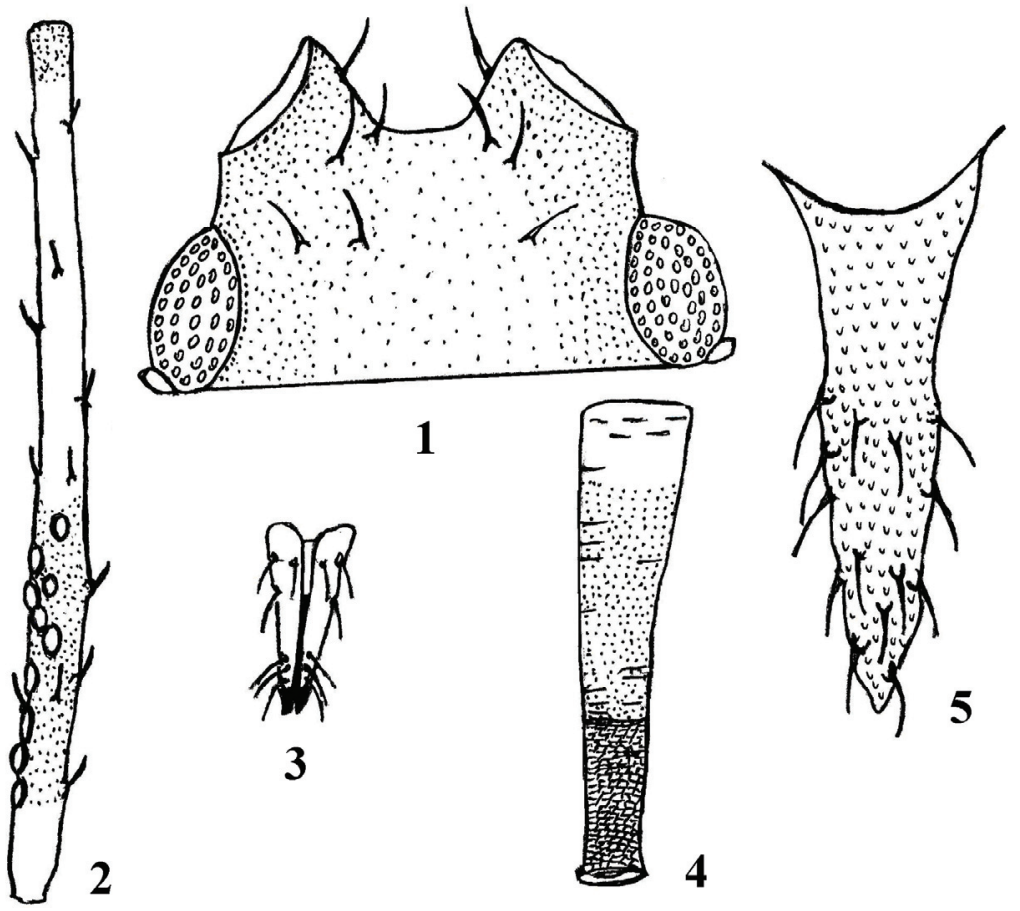

Figs 1-5. Macrosiphoniella aizhanae Kadyrbekov, sp. n., apterous viviparous female. 1 head; 2 - third antennal segment; 3 - ultimate rostral segment; 4 - siphunculus; 5 - cauda.

NATURAL COLORATION. Body is light green or light pink without slim, tibiae and siphunculi are dark brown.

MEASUREMENTS (holotype). Body 2.42; antennae 2.73-2.75: III 0.74, IV 0.51 , V $0.43-0.44$, VI $0.81-0.83(0.19+0.62-0.64)$; siphunculi $0.39-0.40$; cauda 0.41 ; ultimate rostral segment 0.14 ; second segment of hind tarsus 0.17 .

HOST PLANT. Pseudolinosyris grimii (Rgl. et Schrenk) Novopokr. (Asteraceae).

BIONOMY. Aphids live on the stems of flowers.

DIAGNOSIS. The new species belongs to the group of species that lack antesiphuncular sclerites. Among these species, by the depth of the frontal groove and the large size of the body, it is close to M. tapuskae (Hottes et Frison, 1931). M. aizhanae Kadyrbekov sp. n. differs from this species by shorter siphunculi ratio to the body length (0.14-0.18 compared to $0.25-0.38)$ and cauda length (0.9-1.0 vs. 1.8-2.3) and the proportion of the processus terminalis to the base of the 6th antennal segment (3.0-3.8 and 4.2-5.3).

DISTRIBUTION. Rock slopes of mountains.

ETYMOLOGY. The species is named after my wife, an entomologist and constant companion in expeditions. 
Macrosiphoniella (s. str.) scopariae deserticola Kadyrbekov, subsp. n. http://zoobank.org/NomenclaturalActs/13312DB6-F34B-4AC1-B48A-48821EC71759 Figs 6-13

TYPE MATERIAL. Holotype: apterous viviparous female, slide No 1852, South Kazakhstan: Kyzylorda region, north shore of Aral Sea, $250 \mathrm{~km} \mathrm{NW}$ of Aralsk Town, on Artemisia tomentella Trautv., 3.VI 1990, leg. R.Kh. Kadyrbekov. Paratypes: 3 alate viviparous females, 2 apterous viviparous females together with holotype; 1 alate viviparous female, 1 apterous viviparous female, No 1850, South Kazakhstan: Kyzylorda region, north shore of Aral Sea, $250 \mathrm{~km}$ NW of Aralsk Town, on Artemisia tomentella Trautv., 3.VI 1990, leg. R.Kh. Kadyrbekov; 3 fundatrix, slide No 4560, South-East Kazakhstan: Almaty region, Ile valley, $17 \mathrm{~km}$ SE of Zharkent Town, on Artemisia scoparia Waldst. et Kit., 5.V 2013, leg. Kh. Kadyrbekov.

DESCRIPTION. Fundatrix (by 3 specimens). Body is oval, 2.55-2.79, larger than apterous viviparous female. Frontal groove is lesser deep than apterous viviparous female, with distinct antennal tubercles, $0.25-0.30$ of the distance between bases of first antennal segments. Frontal hairs (0.046-0.058) long, pointed, 1.5-1.7 to basal diameter of 3rd antennal segment. Antennae normal, six-segmented, are shorter than apterous viviparous female, $1.03-1.08$ of body length. Third segment is $1.2-1.3$ of 4 th one, $0.65-0.68$ of 6 th segment, $0.80-0.89$ of the processus terminalis. Processus terminalis is shorter than apterous viviparous female, 3.2-3.3 of the base of 6th segment. Secondary rhinaria in number 3-4 are developed on the base of the 3 rd segment. Hairs on the 3rd segment (0.035) are pointed, equal to its basal diameter. Rostrum reaches before to the hind coxae. Its ultimate rostral segment slender, not stiletto shaped, 0.77-0.81 of the second segment of hind tarsus, 0.59-0.62 of the base of 6th segment, with 4-6 accessory hairs. Siphunculi are cylindrical with distinct flanges, shorter than apterous viviparous female, $0.15-0.20$ of body length, 1.231.37 of cauda length. Reticulated zone developed on the $0.22-0.26$ of their length. Cauda is long conic with pointed apex and slow strap in base half, 2.0-2.4 of the second segment of hind tarsus, with 11-13 long pointed hairs. Second segment of hind tarsus is $0.77-0.81$ of the base of 6th segment. Dorsal hairs $(0.069)$ pointed, 2 times to the basal diameter of 3rd antennal segment. There are 18-20 hairs on 3rd tergite, 6-7 between siphunculi and 4-6 ones on the 8 th tergite. Genital plate is broad oval with 2 hairs on disk and 6-8 ones along its posterior margin. Legs normal developed. First tarsal segment with 3:3:3 hairs.

COLOR ON SLIDE. Head, clypeus, 3rd-4th rostral segments, 1st-2nd, apex of 3 rd, proximal half of 4th, 5-6th antennal segments, femora (except the base), base and apex of tibiae, tarsi, siphunculi, cauda are dark brownish; middle part of tibiae, anal and genital plates are pale-brownish. Antesiphuncular sclerites are absent.

NATURAL COLORATION. Body is green with slim, head, antennae, legs, siphunculi, cauda are dark brown.

MEASUREMENT OF FUNDATRIX. Body 2.71; antennae 2.80-?: III 0.620.63, IV 0.50-0.52, V 0.47-0.48, VI 0.91-? (0.21+0.70-?); siphunculi 0.48-0.51; cauda 0.39 ; ultimate rostral segment 0.13 ; second segment of hind tarsus 0.17 . 


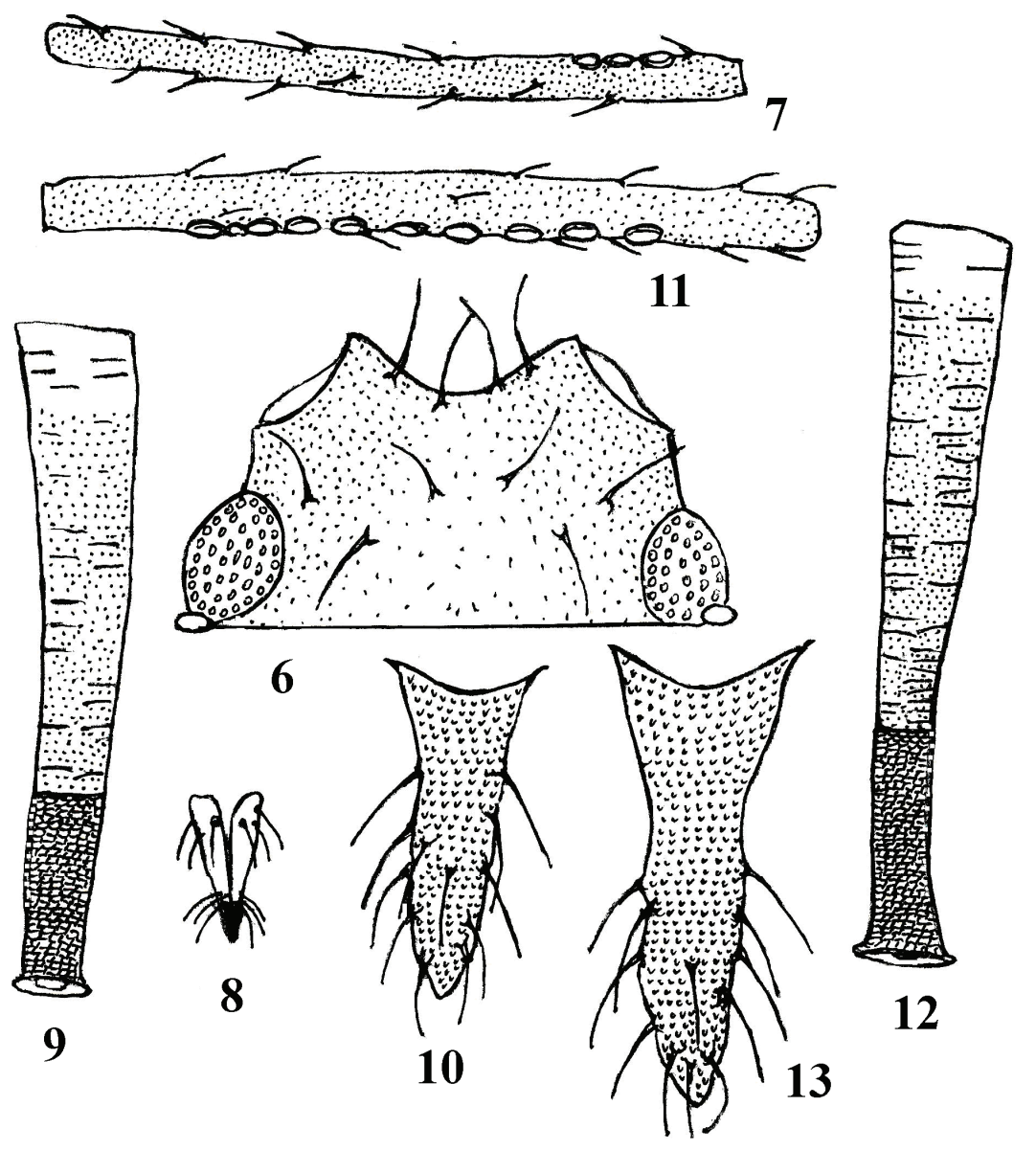

Figs 6-13. Macrosiphoniella scopariae deserticola Kadyrbekov, ssp. n. 6-10 - apterous viviparous female: 6 - head; 7 - third antennal segment; 8 - ultimate rostral segment; 9 siphunculus; 10 - cauda; 11-13 - alate viviparous female: 11 - third antennal segment; 12 siphunculus; 13 - cauda.

Apterous viviparous female (by 4 specimens including holotype). Body is elliptic, 2.29-2.40, lesser than fundatrix. Frontal groove is more deep than fundatrix, with distinct antennal tubercles, $0.30-0.35$ of the distance between bases of first antennal segments (Fig. 6). Frontal hairs (0.058-0.069) long, pointed, 1.5-2.0 times to basal diameter of 3rd antennal segment. Antennae normal, six-segmented, are longer than fundatrix, $1.13-1.20$ of body length. Third segment is $1.10-1.23$ of 4 th one, $0.63-0.70$ of the 6th segment, $0.81-0.91$ of the processus terminalis (Fig. 7). Processus terminalis is longer than fundatrix, 3.3-3.8 of the base of 6th segment. Secondary rhinaria in number 2-4 are developed on the base of the 3rd segment (Fig. 
7). Hairs on the 3rd segment (0.035-0.046) are pointed, 1.5-2.0 times to its basal diameter. Rostrum reaches before up to the hind coxae. Its ultimate rostral segment slender not stiletto shaped (Fig. 8) $0.72-0.81$ of the second segment of hind tarsus, $0.62-0.72$ of the base of 6th segment, with 4-6 accessory hairs. Siphunculi are cylindrical with distinct flanges, longer than fundatrix, $0.20-0.22$ of body length, $1.20-1.36$ of cauda length (Fig. 9). Reticulated zone developed on the $0.20-0.28$ of their length. Cauda is long conic with pointed apex and slow strap in base half, 2.22.5 of the second segment of hind tarsus, with 12-15 long pointed hairs (Fig. 10). Second segment of hind tarsus is $0.8-0.9$ of the base of 6th segment. Dorsal hairs (0.069-0.075) pointed, 1.7-2.2 times to the basal diameter of 3rd antennal segment. There are 18-20 hairs on 3rd tergite, 6-7 between siphunculi and 4-6 ones on the 8 th tergite. Genital plate is broad oval with 2 hairs on disk and 6-8 ones along its posterior margin. Legs normal developed. First tarsal segment with 3:3:3 hairs.

COLOR ON SLIDE. Head, clypeus, antennae, anal and genital plates are palebrownish. Ultimate rostral segment, femora (except the base), tibiae (occasionally with light brownish middle parts), tarsi, siphunculi (except the base), cauda are dark brownish. Antesiphuncular sclerites are absent.

NATURAL COLORATION. Body is green with slim, head, legs, siphunculi, cauda are dark brown.

MEASUREMENT OF HOLOTYPE. Body 2.32; antennae 2.61-2.66: III 0.59, IV 0.48 , V 0.45-0.47, VI $0.85-0.88$ (0.20+0.65-0.68); siphunculi 0.46-0.48; cauda 0.37 ; ultimate rostral segment 0.13 ; second segment of hind tarsus 0.16 .

Alate viviparous female (by 4 specimens). Body is elliptic, 2.49-3.19, more than apterous viviparous female. Frontal groove is more deep, with distinct antennal tubercles, $0.30-0.35$ of the distance between bases of first antennal segments. Frontal hairs (0.035-0.058) pointed, lesser than apterous viviparous female, 1.0-1.5 times to the basal diameter of 3rd antennal segment. Antennae normal, six-segmented, $1.12-1.24$ of body length. Third segment is $1.20-1.32$ of 4 th one, $0.70-0.75$ of the 6th segment, $0.91-0.99$ of the processus terminalis. Processus terminalis is longer than fundatrix and apterous viviparous female, 3.5-4.0 times to the base of 6th segment. Secondary rhinaria in number $8-15$ are developed on the all length of the 3rd segment (Fig. 11). Hairs on the 3rd segment (0.029-0.040) are shorter than apterous viviparous female, pointed, $0.8-1.0$ times to its basal diameter. Rostrum reaches before up to the hind coxae. Its ultimate rostral segment slender, not stiletto shaped, $0.72-0.73$ of the second segment of hind tarsus, $0.58-0.65$ of the base of 6 th segment, with 4-6 accessory hairs. Siphunculi are cylindrical with distinct flanges, $0.16-0.22$ of body length, 1.2-1.6 times to cauda length (Fig. 12). Reticulated zone developed on the $0.20-0.30$ of their length. Cauda is long conic with pointed apex and strap in base half, 2.0-2.3 of the second segment of hind tarsus, with 10-12 long pointed hairs (Fig. 13). Second segment of hind tarsus is $0.78-0.90$ of the base of 6th segment. Dorsal hairs $(0.046-0.069)$ pointed, $1.3-1.7$ times to the basal diameter of 3rd antennal segment. There are 18-20 hairs on 3rd tergite, 6-7 between siphunculi and 4-6 ones on the 8th tergite. Genital plate is broad oval with 2 hairs on disk and 6-8 ones along its posterior margin. Legs normal developed. First tarsal segment with $3: 3: 3$ hairs. 
COLOR ON SLIDE. Head, antennae, clypeus, rostrum, thorax, femora (except the base), coxae, tibiae, tarsi, siphunculi, cauda are dark brownish; trochanters, anal and genital plates are pale-brownish. Antesiphuncular and other sclerites are absent.

NATURAL COLORATION. Body is green with slim, head, thorax, legs, siphunculi, cauda are dark brown.

MEASUREMENT OF ALLOTYPE. Body 2.99; antennae 3.34-?: III 0.79-0.83, IV 0.66, V 0.62-0.63, VI 1.03-? (0.23+0.80-?); siphunculi 0.56-0.58; cauda 0.40; ultimate rostral segment 0.13 ; second segment of hind tarsus 0.18 .

HOST PLANT. Artemisia (Oligosporus) arenaria DC., A. (O.) scoparia Waldst. et Kit., A. (O.) tomentella Trautv. (Asteraceae).

BIONOMY. Aphids live on the stems to the flowers.

DIAGNOSIS. The new subspecies is basically similar to the nominative. $M$. scopariae deserticola Kadyrbekov, ssp. n. differs from M. scopariae scopariae Bozhko, 1959 by the absence of antesiphuncular and other sclerites on the abdomen in all seasonal morphs, lighter coloring of the head, antennae and legs in wingless viviparous females, somewhat lower ratio of siphunculi to body length in apterous viviparous females $(0.20-0.22$ against $0.23-0.25)$ and, on average, somewhat more hairs on the cauda (12-15 compared to 10-11).

DISTRIBUTION. Sandy deserts of South Kazakhstan.

\section{Macrosiphoniella (s. str.) altaica Ivanovskaja, 1971}

Macrosiphoniella (s. str.) altaica Ivanovskaja, 1971: 6, fig. 2 (holotype - apterous viviparous female, Russia: Russian Altai, Bolshoy Jaloman, 10.VII 1963, leg. Ivanovskaja; in the Biological Institute, SO RAN, Novosibirsk).

Macrosiphoniella (s. str.) longirostrata Holman et Szelegiewicz, 1974: 171, fig. 2A (holotype - apterous viviparous female, Mongolia: $40 \mathrm{~km}$ N. of Sain Sand, 24.VII 1963, leg. H. Szelegiewicz; in the Zoological Institute in Warsaw, Poland); syn. n.

NOTES. When comparing $M$. altaica and M. longirostrata (Table 1) according to the values of the main morphological characters, there is no noticeable difference between these taxa. In addition, they live on the same host plant Artemisia frigida and species was described from adjacent territories (Russian Altai and Mongolia). In our opinion $M$. longirostrata is a junior synonym of $M$. altaica.

\section{Macrosiphoniella khinganica Pashtshenko, 1998, stat. n.}

Macrosiphoniella pulvera khinganica Pashtshenko, 1998: 1369, , figs 1(6-10) (holotype apterous viviparous female, Russia: Amur region, Kundur village, Khingan reserve, 20.VII 1988, leg. Pashtshenko; in Federal Scientific Center of the East Asia Terrestrial Biodiversity DVO RAN, Vladivostok).

NOTES. This taxon has been described as a subspecies of $M$. pulvera (Walker, 1948) (Pashtshenko, 1998). However, a comparison of former with M. pulvera (Table 1) showed the presence of a number of differences between them in the ratio of the siphunculi to the body $(0.10-0.11$ vs. $0.13-0.17)$ and the cauda $(0.7-0.8$ compared to $0.80-0.95)$, the ultimate rostral segment and the second segment of the 
hind tarsus (1.0-1.1 and $0.85-0.95)$, the processus terminalis to the base of the 6th antennal segment (2.5-2.9 against 3.0-3.5). I supposed that based on the above differences $M$. khinganica deserves the species status.

Table 1. Values of morphological features of some taxa of Macrosiphoniella

\begin{tabular}{l|c|c|c|c}
\hline \multicolumn{1}{c|}{ Characters } & M. altaica & M. longirostrata & $\begin{array}{l}\text { M. pulvera } \\
\text { pulvera }\end{array}$ & $\begin{array}{l}\text { M. pulvera } \\
\text { khinganica }\end{array}$ \\
\hline Siphunculi/Body & 0.23 & $0.15-0.22$ & $0.13-0.17$ & $0.10-0.11$ \\
\hline Siphunculi/cauda & $1.1-1.2$ & $1.1-1.4$ & $0.80-0.95$ & $0.7-0.8$ \\
\hline Reticulated zone & $0.45-0.50$ & $0.45-0.50$ & $0.45-0.55$ & $0.51-0.60$ \\
\hline $\begin{array}{l}\text { Ultimate rostral segment/ } \\
\text { 2nd segment of hind tarsus }\end{array}$ & $1.4-1.5$ & $1.30-1.5$ & $0.85-0.95$ & $1.0-1.1$ \\
\hline $\begin{array}{l}\text { Number of hairs on } \\
\text { ultimate rostral segment }\end{array}$ & $6+6$ & $6+6$ & $6+6$ & $6+6$ \\
\hline $\begin{array}{l}\text { Processus terminalis/ base } \\
\text { of 6th antennal segment }\end{array}$ & 3.5 & $3.2-3.5$ & $3.0-3.5$ & $2.5-2.9$ \\
\hline $\begin{array}{l}\text { Length of hairs on 3rd } \\
\text { antennal segment/ its } \\
\text { basal diameter }\end{array}$ & 1.5 & 1.3 & $0.7-1.0$ & $?$ \\
\hline $\begin{array}{l}\text { Number of secondary } \\
\text { rhinaria on 3rd antennal } \\
\text { segment }\end{array}$ & $5-6$ & $2-6$ & $2-7$ & $2-3$ \\
\hline Number of hairs on cauda & 10 & $9-12$ & $14-20$ & $15-17$ \\
\hline
\end{tabular}

\section{Macrosiphoniella aktashica aktashica (Nevsky, 1928)}

Macrosiphum aktashicum aktashicum Nevsky, 1928: 182 (holotype - apterous viviparous female, Kazakhstan: Karjantau range, Aktash, in the Zoological institute RAN, St. Petersburg).

Macrosiphum aktashicum hirsutum Danijarova, 1979: 389, fig. 1 (holotype - apterous viviparous female, Tajikistan: Hissar Range, Kondara, 22.VII 1977; in the Institute Zoology and Parasitology AN Tajikistan, Dushanbe); syn. n.

NOTES. It should be noted that, according to the morphological features given in Table 2, we see no difference between M. aktashica aktashica (Nevsky, 1928) and M. aktashica hirsuta (Danijarova, 1979). Thus, M. aktashica hirsuta (Danijarova, 1979 ) is synonymized here with M. aktashica aktashica (Nevsky, 1928).

\section{Macrosiphoniella aktashica tapuskae (Hottes et Frison, 1931), stat. n.}

Macrosiphum tapuskae Hottes et Frison, 1931: 327 (holotype - apterous viviparous female, USA: Illinois, in the collection of Natural History Survey, Urbana, Illinois).

NOTES. The difference between Macrosiphoniella tapuskae (Hottes et Frison, 1931) and M. aktashica (Nevsky, 1928) is small, but stable, noticeable in the ratio of the 4th and 3rd segments of the antennae, siphunculi and cauda, the number of hairs on the cauda (Table 2). We believe that these differences allow us to consider these species as subspecies of one species. 
Table 2. Values of morphological traits in the species complex Macrosiphoniella aktashica

\begin{tabular}{l|c|c|c}
\hline \multicolumn{1}{c|}{ Characters } & $\begin{array}{l}\text { M. aktashica } \\
\text { tapuskae }\end{array}$ & $\begin{array}{l}\text { M. aktashica } \\
\text { aktashica }\end{array}$ & $\begin{array}{l}\text { M. aktashica } \\
\text { hirsuta }\end{array}$ \\
\hline Siphunculi/ Body & $0.25-0.38$ & $0.30-0.32$ & $0.30-0.32$ \\
\hline Siphunculi/ Cauda & $1.8-2.3$ & $2.3-2.6$ & $2.0-2.5$ \\
\hline $\begin{array}{l}\text { Ultimate rostral segment/ } \\
\text { 2nd segment of hind tarsus }\end{array}$ & $1.0-1.1$ & $1.0-1.1$ & $?$ \\
\hline 4th/3rd antennal segment & $0.7-0.9$ & $0.97-1.10$ & $0.85-1.0$ \\
\hline $\begin{array}{l}\text { Processus terminalis/ base of } \\
\text { 6th antennal segment }\end{array}$ & $4.2-5.3$ & $4.0-5.5$ & $4.5-4.7$ \\
\hline $\begin{array}{l}\text { Number of secondary } \\
\text { rhinaria on 3rd antennal } \\
\text { segment of alate viviparous } \\
\text { females }\end{array}$ & $28-70$ & $?$ & $33-40$ \\
\hline $\begin{array}{l}\text { Number of secondary } \\
\text { rhinaria on 3rd antennal } \\
\text { segment of apterous } \\
\text { viviparous females }\end{array}$ & $6-23$ & $7-8$ & $7-8$ \\
\hline Number of hairs on cauda & $8-16$ & $6-8$ & $6-8$ \\
\hline
\end{tabular}

Key to the light green and green Palearctic species from the nominative subgenus Macrosiphoniella without dark abdominal sclerites

1(44) Siphunculi are equal or longer than the cauda.

2(5) Reticulated zone of siphunculi is $0.12-0.20$ of their length.

3(4) Forth antennal segment $0.7-0.9$ of 3rd antennal segment length. Siphunculi 1.8-2.3 of cauda length. Cauda with 8-16 hairs. On the Achillea millefolium, Matricaria inodora, Tanacetum spp. Holarctic M. aktashica tapuskae (Hottes et Frison, 1931)

4(3) Forth antennal segment $0.95-1.10$ of 3rd antennal segment length. Siphunculi 2.0-2.6 of cauda length. Cauda with 6-8 hairs. On the Tanacetum spp., Achillea spp. Kazakhstan (south), Uzbekistan, Tajikistan, Afghanistan ........ M. aktashica aktashica (Nevsky, 1928)

5(2) Reticulated zone of siphunculi is not lesser 0.25 of their length.

6(9) Frontal groove is almost straight, frontal tubercles absent.

7(8) Ultimate rostral segment 1.2-1.5 times to the second segment of hind tarsus. Reticulated zone of siphunculi is $0.35-0.45$ of their length. Tibiae pale to the middle as body color. On the Artemisia globella, A. sp. Kazakhstan, Mongolia ........ M. cedmidi Szelegiewicz, 1963

8(7) Ultimate rostral segment 1.0-1.2 of the second segment of hind tarsus. Reticulated zone of siphunculi is $0.5-0.6$ of their length. Tibiae are dark brown. On the Artemisia princeps, A. pectinata. Central and Eastern Kazakhstan, Russia (Far East), Korea.

M. taesongsanensis Szelegiewicz, 1980

9(6) Frontal groove is distinct, frontal tubercles are visible.

10 (23) Reticulated zone of siphunculi is $0.25-0.40$ of their length.

11(12) Siphunculi $0.25-0.28$ of the body length and 1.8-2.1 times of the cauda length. Processus terminalis 5.0-5.5 times the base of 6th antennal segment. On the Leucanthemum spp. South Europe

M. leucanthemi (Ferrari, 1872) 
12(11) Siphunculi not more 0.25 of the body length and not more 1.7 time of the cauda length.

13(16) Siphunculi 1.5-1.7 times of the cauda length.

14(15) Third antennal segment is shorter of the forth antennal segment. Cauda with more than 20 hairs. On the Artemisia dracunculus. Kyrgyzstan .... M. dracunculi Umarov, 1964

15(14) Third antennal segment is always longer of the forth antennal segment. Cauda with 812 hairs. On the Artemisia dracunculus, A. scoparia. South Kazakhstan

M. alatavica (Nevsky, 1928)

16(13) Siphunculi are $1.0-1.3$ of the cauda length.

17(18) Processus terminalis 1.8-2.2 times the base of 6th antennal segment. Cauda with 14 20 hairs. Tibiae pale to middle as body color. On the Karelinia caspia. Kazakhstan, China (Xinjiang) ........................... Mareliniae Kadyrbekov, Renxin et Shao, 2002

18(17) Processus terminalis 2.1-3.2 times the base of 6th antennal segment. Cauda with 20 30 hairs. Tibiae and cauda are dark brown.

19(22) Third antennal segment 0.9-1.0 times the 6th antennal segment. Siphunculi are 1.21.3 of the cauda length. Reticulated zone of siphunculi is $0.30-0.35$ of their length.

20(21) Third antennal segment with 3-5 secondary rhinaria. Siphunculi $0.15-0.20$ of body length. Cauda with 20-30 hairs. On the Artemisia (Seriphidium) spp. Russia (Lower Volga), Kazakhstan, Kyrgyzstan, China (Xinjiang) .................. M. kirgisica Umarov, 1964

21(20) Third antennal segment with 34-38 secondary rhinaria. Siphunculi 0.24 of body length. Cauda with 17-19 hairs. On the Artemisia sp. China (Xinjiang)

M. huochengensis Zhang, Chen et Zhong, 1999

22(19) Third antennal segment is 1.1-1.3 times of the 6th antennal segment. Siphunculi are $1.0-1.1$ of the cauda length. Reticulated zone of siphunculi is $0.20-0.26$ of their length Cauda with 18-21 hairs. On the Lepidolopha filifolia. South Kazakhstan (Karatau ridge)

\section{M. karatavica Kadyrbekov, 2015}

23(10) Reticulated zone of siphunculi is not lesser 0.45 of their length.

24(31) Third antennal segment with not lesser than 8 secondary rhinaria.

25(26) Third antennal segment with 23-73 secondary rhinaria. Processus terminalis 3.5-4.8 times the base of 6th antennal segment. On the Artemisia arctica, A. tanacetifolia, Tanacetum boreale. Eastern Kazakhstan, Russia (Eastern Siberia, Chukotka)

M. borealis Pashtshenko, 1998

26(25) Third antennal segment with not more 20 secondary rhinaria. Processus terminalis 2.5-3.3 times the base of 6th antennal segment.

27(30) Frontal groove deeps, antennal tubercles high. Siphunculi 1.04-1.10 times the cauda length.

28(29) Third antennal segment with 12-18 secondary rhinaria. Processus terminalis 2.7-3.3 times the base of 6th antennal segment. Siphunculi $0.16-0.18$ of body length. Cauda with 23-29 hairs. On the Artemisia vulgaris, A. sp. India

M. kalimpongensis Basu et Raychaudhuri, 1976

29(28) Third antennal segment with 10 secondary rhinaria. Processus terminalis 2.5-2.6 times the base of $6^{\text {th }}$ antennal segment. Siphunculi $0.20-0.21$ of body length. Cauda with 14-18 hairs. On the Artemisia sp. China ... M. huaidensis Zhang, 1980

30(27) Frontal groove and antennal tubercles are low. Siphunculi 1.2-1.4 times the cauda length. Cauda pale, with 12-15 hairs. Tibiae of hind legs pale with dark apices. On the Artemisia (Seriphidium) spp. Hungary, Israel, Kazakhstan

M. szalaymarzsoi Szelegiewicz, 1978

31(24) Third antennal segment with not more than 7 secondary rhinaria. 
32(33) Ultimate rostral segment is $0.67-0.87$ of second segment of hind tarsus. On the Artemisia (Oligosporus) spp. Southern Kazakhstan

M. scopariae deserticola Kadyrbekov, sp. n.

33(32) Ultimate rostral segment equal or longer of second segment of hind tarsus.

34(35) Siphunculi not lesser 0.25 of the body length and more than 1.55 times the cauda length. Reticulated zone of siphunculi $0.50-0.55$ of their length. Processus terminalis 0.8 0.9 of 3rd antennal segment and 2.8-3.2 times the base of 6th antennal segment. Tibiae are dark brown. On the Artemisia sp. Tajikistan .... M. lidiae Umarov, 1966

35(34) Siphunculi not more 0.23 of the body length and not more than 1.5 times the cauda length.

36(43) Ultimate rostral segment is $1.0-1.2$ of the second segment of hind tarsus.

$37(42)$ Depth of frontal groove is $0.15-0.19$ of the distance between apices of the antennal tubercles. Tibiae of middle and hind legs are dark brown, sometimes pale brown in the middle. Processus terminalis is longer or equal to the 3rd antennal segment in norm.

38(39) Siphunculi are 1.0-1.2 of the cauda length. Cauda is brown as siphunculi with 12-19 hairs. On the Artemisia terrae-alba, A. sublessingiana. Southern, Central, Eastern Kazakhstan M. terraealbae Kadyrbekov, 2000

39(38) Siphunculi not lesser 1.4 of the cauda length. Cauda with 7-10 hairs.

40(41) Third antennal segment with 3-5 secondary rhinaria. Processus terminalis 3.0-3.5 of the base of 6th antennal segment. Ultimate rostral segment with 6 accessory hairs. Siphunculi $1.40-1.45$ of the cauda length. On the Artemisia ferganensis. Tajikistan

M. tadzhicana Narzikulov, 1958

41(40) Third antennal segment with $2-3$ secondary rhinaria. Processus terminalis $1.70-1.75$ of the base of 6th antennal segment. Ultimate rostral segment with 8 accessory hairs. Siphunculi $1.50-1.55$ of the cauda length. On the Artemisia scoparia. India

M. lambersi Verma, 1971

42(37) Depth of frontal groove is $0.21-0.25$ of the distance between apices of the antennal tubercles. Tibiae of middle and hind legs pale as body color, except darkish bases and apices. Processus terminalis is shorter or equal to the 3rd antennal segment in norm. On the Artemisia (Seriphidium) spp. Russia (Lower Volga), Kazakhstan, Tajikistan, China (Xinjiang) ............................................. seriphidii Kadyrbekov, 2000

43(36) Ultimate rostral segment is $1.30-1.45$ of the second segment of hind tarsus. On the Artemisia frigida, A. austriaca. Kazakhstan, Russia (Russian Altai), Mongolia

M. altaica Ivanovskaja, 1971

44(1) Siphunculi are equal or shorter than the cauda.

42(53) Ultimate rostral segment is equal or longer than the second segment of hind tarsus

43(48) Frontal groove is visible with distinct antennal tubercles.

44(45) Ultimate rostral segment is 1.3-1.6 times the second segment of hind tarsus with 8-9 accessory hairs. Cauda with 8-10 hairs. Tibiae pale with dark apices. On the Artemisia stelleriana. Russia (Sakhalin) ........................ sachalinensis Pashtshenko, 1998

45(44) Ultimate rostral segment is not more 1.25 times the second segment of hind tarsus with 6 accessory hairs. Cauda with 20-30 hairs. Tibiae are dark brown or blackish.

46(47) Frontal groove is very deep, 0.30 of the distance between apices of the antennal tubercles. Processus terminalis is 3.4-3.7 times the base of 6th antennal segment. Siphunculi are $0.15-0.16$ of the body length. Reticulated zone of siphunculi $0.3-0.4$ of their length. On the Artemisia stolonifera. Russia (Far East) .... M. sichotealiensis Pashtshenko, 1998

47(46) Frontal groove is $0.15-0.18$ of the distance between apices of the antennal tubercles. Processus terminalis is 2.3-3.1 times the base of 6th antennal segment. Siphunculi are $0.10-0.13$ of the body length. Reticulated zone of siphunculi $0.5-0.7$ of their length. On the Artemisia vulgaris, A. mongolica, A. princeps, A. spp. Russia (Far East), Korea, China, Japan, South-East Asia, India M. yomogifoliae (Shinji, 1924) 
48(43) Frontal groove is almost straight, frontal tubercles absent.

49(50) Ultimate rostral segment is 1.2-1.5 times the second segment of hind tarsus. Reticulated zone of siphunculi $0.35-0.45$ of their length. On the Artemisia globella and Artemisia sp. Kazakhstan, Mongolia M. cedmidi Szelegiewicz, 1963

50(49) Ultimate rostral segment is $1.0-1.2$ of the second segment of hind tarsus. Reticulated zone of siphunculi $0.5-0.6$ of their length.

51(52) Siphunculi are $0.10-0.12$ of body length. Cauda with $15-17$ hairs. Tibiae are pale as body color with dark apices. On the Artemisia mongolica. Russia (Far East)

M. khinganica Pashtshenko, 1998

52(51) Siphunculi are 0.14-0.17 of body length. Cauda with 9-12 hairs. Tibiae are dark brown. Kazakhstan, Korea, Russia (Far East) M. taesongsanensis Szelegiewicz, 1980

53(42) Ultimate rostral segment is always shorter than the second segment of hind tarsus.

54(67) Tibiae are dark brown or blackish, rear pale brown to middle, but not as body color.

55(56) Third antennal segment is always shorter than 4th antennal segment. On the Artemisia sieversiana, A. sp. Northern and Eastern Kazakhstan, Russia (West Siberia)

M. sibirica Ivanovskaja, 1971

56(55) Third antennal segment is always longer than 4th antennal segment.

57(60) Cauda with 22-35 hairs.

58(59) Third antennal segment with 8-34 secondary rhinaria. Processus terminalis is $3.8-4.2$ times the base of the 6th antennal segment. Reticulated zone of siphunculi is $0.35-0.45$ of their length. On the Achillea ptarmica. Europe ..... M. ptarmicae Hille Ris Lambers, 1956 59(58) Third antennal segment with $12-45$ secondary rhinaria. Processus terminalis is 2.9 3.5 times the base of the 6th antennal segment. Reticulated zone of siphunculi is $0.45-0.55$ of their length. On the Achillea, Tanacetum, Matricaria. Holarctic

M. tanacetaria (Kaltenbach, 1843)

60(57) Cauda with not more 20 hairs.

61(64) Third antennal segment with 6-17 secondary rhinaria.

62(63) Third antennal segment is shorter or equal of the processus terminalis. Hairs of 3rd antennal segment 1.5 times its basal diameter. Reticulated zone of siphunculi is $0.50-0.60$ of their length. Cauda with 14-20 hairs. On the Artemisia sieversiana. East and South East Kazakhstan, Mongolia ......................... M. sieversianae Holman et Szelegiewicz, 1974

63(62) Third antennal segment is $1.05-1.20$ of the processus terminalis. Hairs of 3rd antennal segment $0.75-0.85$ of its basal diameter. Reticulated zone of siphunculi is $0.25-0.40$ of their length. Cauda with 10-17 hairs. On the Pseudolinosyris grimii. Southern Kazakhstan

64(61) Third antennal segment with $2-7$ secondary rhinaria.

65(66) Processus terminalis is 2.7-3.2 times the base of the 6th antennal segment. Siphunculi

0.13-0.17 of body length. Cauda with 14-20 hairs. On the Artemisia maritima, A. spp.

Palearctic .................................................. Mulvera (Walker, 1848)

66(65) Processus terminalis is 3.30-3.55 times the base of the 6th antennal segment. Siphunculi 0.08 of body length. Cauda with 10-13 hairs. On the Artemisia scoparia. China (Gansu) M. tszhongi Zhang, Chen et Zhong, 1999

67(54) Tibiae are pale as body color with darkish apices.

63(64) Processus terminalis is 3.7-4.5 times the 3rd antennal segment. Siphunculi are darkish to the apices only. On the Artemisia procera, A. proceraeformis. Ukraine, Kazakhstan .....

M. procerae Bozhko, 1953

64(63) Processus terminalis is not more 3.7 times the base of the 6th antennal segment. Siphunculi are darkish to the apical half.

65(68) Siphunculi 0.13-0.17 of body length. 
66(67) Depth of frontal groove is $0.17-0.19$ of the distance between apices of the antennal tubercles. Siphunculi 0.80-0.95 of cauda length. Cauda with 14-20 hairs. On the Artemisia maritima, A. (Seriphidium) spp. Palearctic M. pulvera (Walker, 1848)

67(66) Depth of frontal groove is $0.23-0.25$ of the distance between apices of the antennal tubercles. Siphunculi $0.70-0.75$ of cauda length. Cauda with 23-30 hairs. On the Artemisia argyi. China (Gansu) ............................ jinghualii Zhang, Chen et Zhong, 1999 66(65) Siphunculi $0.10-0.13$ of body length. On the Artemisia from nominative subgenus.

67(68) Cauda with 15-25 hairs. Hairs of 3rd antennal segment is 1.1-1.8 times its basal diameter. On the Artemisia abrotani, A. absinthium, A. vulgaris, Matricaria inodora. West Palearctic M. abrotani abrotani (Walker, 1852) 68(65) Siphunculi $0.10-0.13$ of body length. On the Artemisia from nominative subgenus.

69(70) Cauda with 15-25 hairs. Hairs of 3rd antennal segment is 1.1-1.8 times its basal diameter. On the Artemisia abrotani, A. absinthium, A. vulgaris, Matricaria inodora. West Palearctic

M. abrotani abrotani (Walker, 1852)

70(69) Cauda with 10-17 hairs. Hairs of 3rd antennal segment is $0.8-1.0$ times its basal diameter.

71(74) Third antennal segment with 4-8 secondary rhinaria.

72(73) Processus terminalis is 3.2-3.6 times the base of the 6th antennal segment and 1.2-1.3 of 3rd antennal segment. On the Artemisia messerschmidtiana, A. annua, A. montana, Tanacetum boreale. Russia (Far East), Korea ..... M. abrotani chosoni Szelegiewicz, 1980

73(72) Processus terminalis is 2.1 times the base of the 6th antennal segment and 0.95-1.02 of 3rd antennal segment. On the Artemisia scopariae. China (Gansu)

M. abrotani hofuchui Zhang, Chen et Zhong, 1999. stat. n.

74(71) Third antennal segment with $2-5$ secondary rhinaria. Processus terminalis is 3.0-3.3 times the base of the 6th antennal segment. On the Artemisia vulgaris, A. sp. Kazakhstan (south east, east), Mongolia M. abrotani sainshandi Szelegiewicz, 1963

\section{REFERENCES}

Basu, R.C. \& Raychaudhuri, D.N. 1976. Studies on the aphids from Eastern India. XXIV. Genus Macrosiphoniella. Oriental Insects, 10: 295-306.

Bozhko, M.P. 1953. New aphids species (Aphididae) from the steppe zone of East Ukraine. Entomologicheskoe Obozrenie, 33: 291-296. [In Russian]

Danijarova, M.M. 1979. New subspecies of Aphids (Homoptera, Aphidinea) from Tajikistan and Afganistan. Doklady Academii nayk Tajikskoy SSR, 22(6): 389-391. [In Russian]

Favret, C. 2018. SF Aphid: Aphid Species File (vesion 5/0). Available from: http:/aphid.species. file,org. (visited June 2018).

Heie, O.E. 1995. The Aphidoidea (Hemiptera) of Fennoscandia and Denmark: VI. Family Aphididae: Part 3 of tribe Macrosiphini of subfamily Aphidinae, and family Lachninae. Fauna Entomologica Scandinavica, 31: 1-217.

Hille Ris Lambers, D. 1938. Contributions to a monograph of the Aphididae of Europe. 1. The genus Macrosiphoniella del Guercio, 1911. Temminckia, 3: 1-47.

Holman, J. \& Szelegiewicz, H. 1974. Aphids of the genus Macrosiphoniella (Homoptera, Aphididae) from Mongolia. Acta Entomologica Bohemoslovaca, 71: 161-177.

Holman, J. \& Szelegiewicz, H. 1978. Further aphids of the genus Macrosiphoniella (Homoptera, Aphididae) from Mongolia. Acta Entomologica Bohemoslovaca, 75: 178-193.

Hottes, F.S. \& Frison, T.N. 1931. Plant-lice of Illinois. Illinois Natural History Survey Bulletin, 19(3): 327-329. 
Ivanovskaja, O.I. 1971. New species of the aphids of subtribe Macrosiphina (Aphididae, Homoptera). P. 5-13. In: New and little known species of Siberia fauna. Vol. 5. Novosibirsk. [In Russian]

Kadyrbekov, R.Kh. 2000. New aphid species of tribe Macrosiphini (Homoptera, Aphididae) from South East Kazakhstan. Selevinia, 9(1-4): 9-17. [In Russian]

Kadyrbekov, R.Kh. 2015. New species of Macrosiphoniella del Guercio, 1911 (Homoptera: Aphididae) from Kazakhstan. Selevinia, 23: 33-34.

Kadyrbekov, R.Kh., Huang, R.X. \& Shao, H.G. 2002. To aphid fauna (Homoptera, Aphididae) of Xinjang-Uygur Region of China. Tethys Entomological Research, 6: 13-32.

Miyazaki, B.M. 1971. A revision of the tribe Macrosiphini of Japan (Homoptera: Aphididae, Aphidinae). Insecta Matsumurana, 34(1): 1-247.

Narzikulov, M.N. 1958. New for science aphids (Homoptera: Aphididae) from the Tajikistan. Trudy AN Tadjikskoi SSR, 89: 15-30. [In Russian]

Nevsky, V.P. 1928. The plant-lice of Middle Asia. I. Entomologishen Mitteilungen, 8: 182 199.

Nevsky, V.P. 1929. Aphids of Middle Asia. Uzbekskaja opytnaja stancija zashity rasteniy, Tashkent. 424 pp. [In Russian]

Pashtshenko, N.F. 1998. Aphids of Macrosiphoniella genus (Homoptera, Aphididae) from the Far East of Russia. Part 2. Description of new species and subspecies of subgenus Macrosiphoniella s. str. Zoologicheskij Zhurnal, 77: 994-1003. [In Russian]

Poljakov, P.P. 1967. Systematic and origin of Compositae. Nauka, Alma-Ata. 336 pp. [In Russian]

Szelegiewicz, H. 1963. Blattläuse (Homoptera, Aphididae) aus der Mongolei. Annales Zoologici, 21: 109-130.

Szelegiewicz, H. 1978. Three new aphid species (Homoptera, Aphidoidea) from Artemisia in Hungary. Acta zoologica Academie Sciences Hungary, 24: 211-218.

Szelegiewicz, H. 1980. Aphids of the genus Macrosiphoniella del Guercio (Homoptera, Aphididae) from the Democratic People's Republic of Korea. Annales Zoologici, 35(25): 419-474.

Umarov, Sh.A. 1964. New species of the aphids of Macrosiphonini group (Homoptera, Aphididae) from the Middle Asia. Izvestia otdelenija biologitscheskich nauk Tadjikskoy SSR, 1(15): 66-73. [In Russian]

Umarov, Sh.A. 1966. New species of the aphids of Macrosiphonini group (Homoptera, Aphididae) from the mountainous regions of Middle Asia. Izvestia otdelenija biologitscheskich nauk Tadjikskoy SSR, 4(25): 87-91. [In Russian]

Verma, K.D. 1971. New genus and two new species of aphids from N. W. India (Homoptera: Aphididae). Bulletin of Entomology, 12(2): 97-99.

Zhang, G.X., Chen, X.L. \& Zhong, T.S. 1999. Family Aphididae. P. 273-508. In: Fauna of agricultural and forestry aphids of Northwest, China: Insecta Homoptera Aphidinea. China Environmental Press, Beijing. [In Chinese with English summary]

Zhang, G.X. \& Zhong, T.S. 1980. New species of Chinese Macrosiphinae (II) (Homoptera, Aphididae. Entomotaxonomia, 2(3): 215-225. [In Chinese with English summary] 